\title{
Spatial and temporal variation of extremely low minimum temperatures in Hungary during the period between 1951 and 2010
}

\author{
Lakatos, L.1, Sümeghy, Z. ${ }^{3}$, Soltész, M. ${ }^{2}$, Szabó, Z. ${ }^{2} \&$ Nyéki, J. ${ }^{2}$ \\ ${ }^{1}$ University of Debrecen, Centre of Agricultural and Applied Economic Sciences, Department of Agricultural \\ Engeneering H-4032 Debrecen, Böszörményi 138, Hungary, lakatos@agr.unideb.hu \\ ${ }^{2}$ University of Debrecen, Institute of Horticulture, H-4032 Debrecen, Böszörményi 138, Hungary \\ ${ }^{3}$ University of Szeged, Department of Climatology and Landscape Ecology H-6722 Szeged, Egyetem u. 2.
}

\begin{abstract}
Summary: For this study, data of 16 meteorological stations have been processed over a period of 60 years with the purpose to reveal the spatial and temporal structure of the frequencies of absolute extreme minima in Hungary with special reference to the surmised global rise of temperatures on a worldwide scale. In the main areas of fruit growing, the monthly or seasonal absolute temperature maxima and minima are presented during the 60 year-long period and projected on the geographical map.

For the main fruit- and vegetable growing regions the probability of winter- and late frosts is of prime interest. The time series of extreme temperatures though did not prove significant changes over the period observed, but the information upon changes and their tendencies is a precious tool being utilised in planning, choice of adequate varieties for a longer period of time in the future.

The deleterious winter frosts experienced in fruit production is not a consequence of a sole drop to a minimum temperature, but of an earlier period of mild temperatures during the winter, which sensibilised the trees. Frequent and extreme variations of temperatures may cause troubles at any time during the year and reduce the yields conspicuously.

We ought to get familiar with the hazards of our climate and find optimal solutions to mitigate the damages expected.

The seasonal and monthly distribution projected on the geographical map we can follow up also the spatial relations and the significance of their occurrence. Coefficients of variation between meteorological happenings at different localities facilitate the calculation of the probability of risks on the surrounding areas.
\end{abstract}

Key words: spatial distribution, temporal distribution, extreme low temperature, 60 year time series, Kriging standard

\section{Introduction, survey of the literature}

The search to reveal changes in climatic hazards on a regional level was the main task of Hungarian climatologists (Bartholy et al. 2003, Domonkos, 2001, Mika, 1988, 1991, Mika et al. 2001). The satiation of the water supply being a compound task of dealing precipitation, building up water reserves in the soil, balances between temperature, evaporation, etc. (Antal 2003, Varga-H. 2003, Kozmáné et. al. 1995).

We are sometimes tempted to feel of getting independent from climatic hazards and may avoid incidences by forecasting excessive cooling downs of temperature. As a matter of fact, greenhouses, plastic tunnels, closed constructions efficient tools on a radical scale and also expensive. In addition, they cannot be used for all kind of cultivated plants. Modelling of the growth of agricultural crops is a new technical possibility. To forecast he changes of the global climate and its effect on yields is a recently initiated branch of research (Harnos, 2003). Estimates of the expected risks depend largely on the radical knowledge of its probability on the growing site (Varga-Haszonits et. al., 2002). E.g. the probability and length of drought periods or the high occurrence of temperature minima may mean a prohibition to risk an attempt to initiate cultivation of drought- or frost-sensitive cultures on the respective site.

The known temperature minima and their risk to occur during the winter is of prime interest mainly in viticulture and in fruit growing for the purpose to develop far reaching strategies. Studies of that type appeared recently (Csapó, 1984, Dunkel et. al. 1984, Fekete, 1980, Szilágyi, 1982, Varga, 2003).

Late spring and early autumn frosts are especially noxious in fruit growing. The damage depends not only on the temperature and its duration but also on the physiological status of the plants (deep rest or induced rest) and the phenophase. Sometimes a little drop of temperature may cause damage if the plant is particularly susceptible. In vegetable growing, the night temperature minima caused by radiation near to the soil are often deleterious. Sites on the bottom of valleys and windless spots are endangered, where the cold air may persist like in a lake, whereas slopes with southern exposition are saved easily. 
Temperature measurements made $2 \mathrm{~m}$ above soil level and where the surface is variable, are unadapted for recognise radiation minima, or with large error only. The check of microclimatic effects is in this case indispensable.

Excessive minimum temperatures are important moments of risk threatening plant growing practices (Antal, 1998). Productivity depends largely on hazards of temperature and water supply. The changes of daily and night temperatures are influencing decisively the photosynthesis as well as respiration and regulate their interaction or balance. On a countrywide level, we have not data representing hour for hour changes of temperature neither on the regional level. However, it is worth while to mention that macroclimatic data may vary markedly depending on the plant stand around the thermometer. During the daily hours, the plant density, height, foliage may cause higher measured data by $3-5{ }^{\circ} \mathrm{C}$, whereas during the night lower readings by $2-3{ }^{\circ} \mathrm{C}$. This fact changes substantially the determination of absolute minima as well as of maxima.

In the future, we should consider that fact for the determination of incidence of excessive low temperatures. At present, we may avoid details of this topic.

\section{Material and method}

We processed the database of meteorological measurements of the period 1951-2010, with special reference to daily minima. Measurements were performed by the OMSZ (Countrywide Meteorological Service) on its 16 stations covering the whole area of Hungary. The question could be put: whether this system would it be adequate for our purpose or not? Obviously, the distribution of the points does not allow the observation of smaller changes of relief. The macroclimatic relations of the country would be adequately represented. Local expositions were not studied in this case. The period of 62 years seems to be sufficient to conclude the information being valid enough and mathematically correct for the practice of growers.

The study was directed to observe spatial and temporal changes in the meteorological data as far as the position of the 16 stations was not altered. The data allowed the construction of geographical maps and the connection of point with isolines by the help of a software Surfer 7.0 and the Kriging method fitted to the background map of the country.

Statistical processing involved the registration of temporal changes, fitting of the regression curves, analyses by the SPSS 11.0 software and tables constructed by the Excel system.

The monthly absolute minima were computed from the daily minima. The variance of the time series of daily minima served for the computation of CV-s (coefficient of variation). The monthly time series was the matter of fitting a linear trend function, which was subject to test its significance. Beside monthly means also seasonal means were calculated for absolute maxima and minima as well as the spatial distribution of the slopes of the trendfunction and of the CV values.

\section{Results}

The spatial distribution of absolute minima was changing zonally in the spring (Figure 1). The zonality would mean that parallel on the SW-NE axis, a massive drop of temperature is observed. For the building up of a zonal distribution, we have to postulate circulation or an action centre. As a consequence of zonal space, in this season we shall see a large spatial gradient of temperature. The most vigorous change is shown along the axis between Kecskemét-Balassagyarmat with a gradient of $9{ }^{\circ} \mathrm{C}$. The lowest spring minima were found on the hills of Zala county and at the eastern side of the Kisalföld (Little Plain). In the eastern part of the Tisza region and in the south, around Villány, the less low absolute minima were during the 62 year long period.

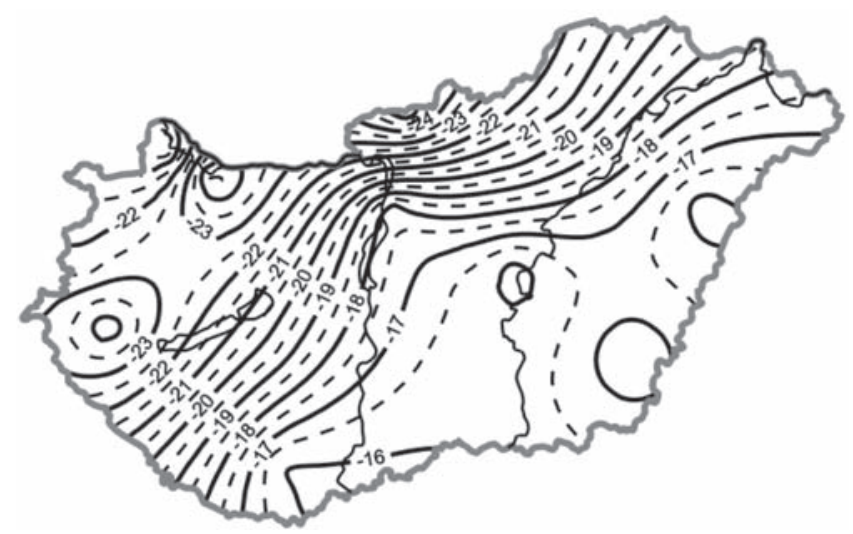

Figure 1 - The spatial distribution of absolute temperature minima in spring measured at 16 stations over a period of 1951-2010

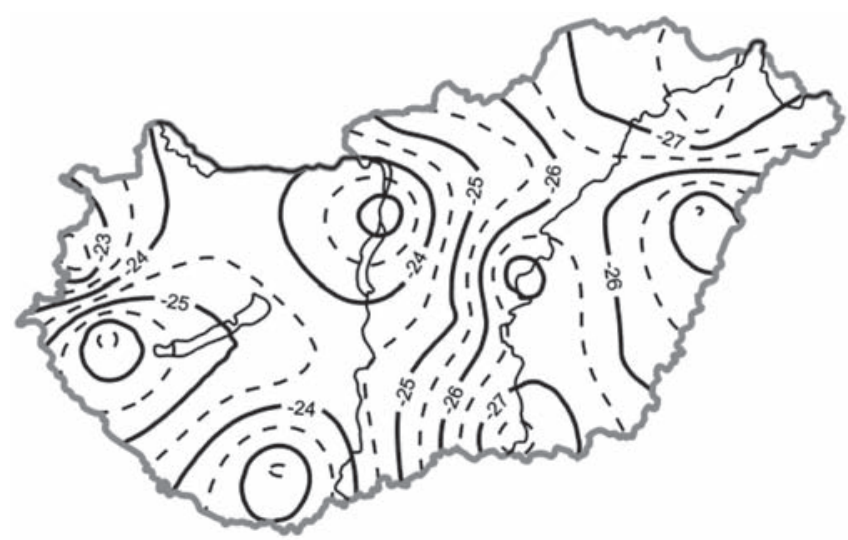

Figure 2 - The absolute minimum temperatures during winter according to data raised at 16 stations over a period of 1951-2010

The differences in absolute maxima over the country diminished and the heterogeneity increased (Figure 2). No univocal increment of a growing bottom temperature was found on the SW-NE axis. As a result of circulation effects, cold air from the eastern plains (of Siberia) is flowing into the Carpathian basin from NE across the passes of the Carpathian mountains in addition from SE through the valley of Danube. During winter however, the main wind is coming from NW carrying Oceanic temperatures or from SW Mediterranean climate. That explains the Tisza region, where 
the Southern and NE parts show the lowest temperatures whereas in Transdanubia, South and NW were the highest winter absolute minima over the last 50 years, about $2{ }^{\circ} \mathrm{C}$ higher than in the east.

After having compared the two seasons, we see that in spring there are the largest differences and in winter, the smallest between localities. The absolute values of minima depend highly from the vertical profile and the exposition of the respectable regions.

The temporal structure of the time series was also extended to the geographical map, and to the distributions of $\mathrm{CV}$ values among the seasonal periods.

The comparison of seasons allows the statement that the absolute minima in spring exhibit the highest spatial distribution and highest CV values (50-70\%) (Table 1). In winter, both, $\mathrm{CV}$ values and spatial differences are lowest $(20-30 \%)$.

Table 1 - Coefficients of variation of the measured absolute minimum temperatures at 16 stations in spring and in winter over a period of 1951-2010

\begin{tabular}{|l|c|c|}
\hline \multicolumn{1}{|c|}{ ABS. MIN TEMP CV } & spring & winter \\
\hline Balassagyarmat & 58.42 & 23.83 \\
\hline Békéscsaba & $\mathbf{4 6 . 3 3}$ & 25.48 \\
\hline Budapest & 65.89 & 27.73 \\
\hline Debrecen & 46.73 & 23.63 \\
\hline Gyór & $\mathbf{7 1 . 8 9}$ & 26.52 \\
\hline Iregszemcse & 66.68 & 27.48 \\
\hline Kecskemet & 57.72 & 27.19 \\
\hline Kompolt & 57.00 & 24.29 \\
\hline Miskolc & 49.22 & 24.09 \\
\hline Mosonmagyaróvár & 70.18 & 23.48 \\
\hline Nyíregyháza & 50.80 & 23.75 \\
\hline Pécs & 66.00 & 25.72 \\
\hline Szeged & 52.47 & 27.77 \\
\hline Szolnok & 53.55 & $\mathbf{2 8 . 1 7}$ \\
\hline Szombathely & 63.95 & 20.91 \\
\hline Zalaegerszeg & 69.90 & 24.01 \\
\hline Min & $\mathbf{4 6 . 3 3}$ & $\mathbf{2 0 . 9 1}$ \\
\hline Max & $\mathbf{7 1 . 8 9}$ & $\mathbf{2 5 . 3}$ \\
\hline Dif & $\mathbf{5 9 . 2}$ & \\
\hline Mean & & 265 \\
\hline
\end{tabular}

The high variability of absolute minima in winter is unfavourable because of the risk of late frosts. Similarly, during winter, the cause of winter frost stems from the high variability. Mild periods may interrupt the rest period of the trees and makes them susceptible when cold periods follow.

The monthly distribution of CV values at the 16 stations show it clearly that in April and October the variability of absolute minima culminate (Figure 3), which means the risk of late spring frosts and of early autumn frosts.

In spring, the highest $\mathrm{CV}$ values prevail in $\mathrm{W}$ especially Kisalföld (Little Plain NW Hungary) (Figure 4). On the
W-E axis, the CV diminishes intensely. The isotherm lines are running in NS direction exhibiting a zonal structure. The CV values are drawing a horizontal gradient, which decreases in the Central Danube-Tisza region $1 \%$ per $10 \mathrm{~km}$ eastward. In Eastern Hungary the $\mathrm{CV}=$ around $50 \%$, whereas in Trandsanubia more than $65 \%$.

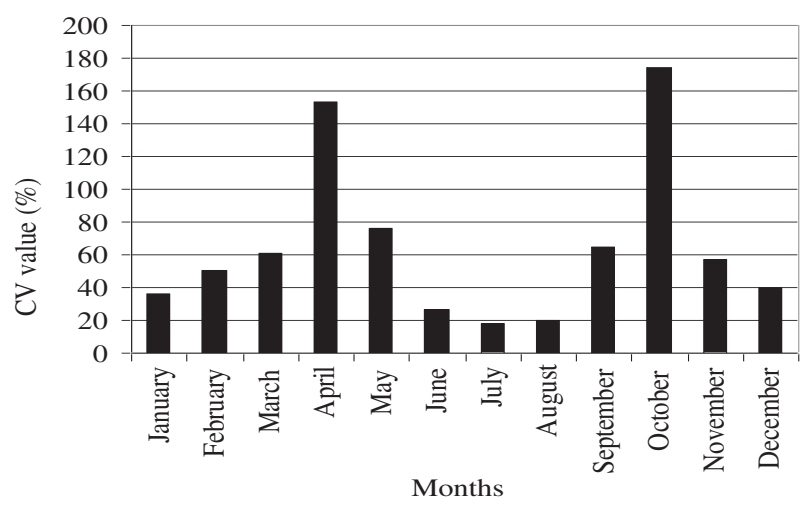

Figure 3 - The mean values of coefficients of variation $(\mathrm{CV})$ of the mean absolute monthly minimum temperatures measured at 16 stations over a period of 1951-2010

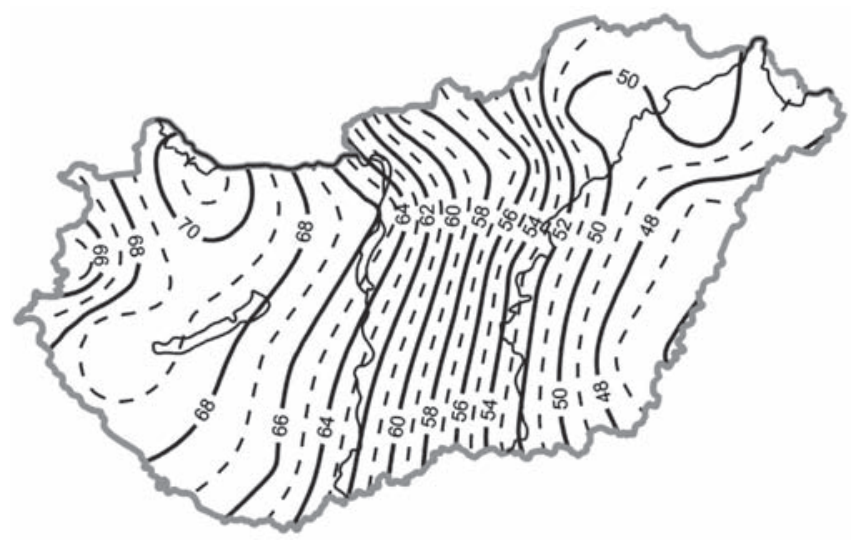

Figure 4 - Mean values of the coefficients of variation (CV) of absolute temperature minima in spring measured at 16 stations over a period of 1951-2010

During winter, the basin effect is more expressed, although the spatial differences are the smallest. In the central areas of the Danube-Tisza region are the highest, in Western Transdanubia and the Subalpine region the lowest values of the $\mathrm{CV}$ (Figure 5). In NE Hungary the low CV values are similar to the West Hungarian region.

Let alone the variability of minimum temperatures, the changes (reduction or increment) of temperatures is expressed by the slope of the functions and this is an important criterion in planning of horticultural production on the long run. As the mean of data of 16 stations, we could state that the slope is steepest in January, when the minima of absolute temperature are increasing, whereas their decreasing is steep in December (Figure 6).

In spring, the increment of absolute minimum temperatures the slope of the function is steep along the SE-NW axis (Figure 7). In the region Viharsarok (SE Hungary), there is 


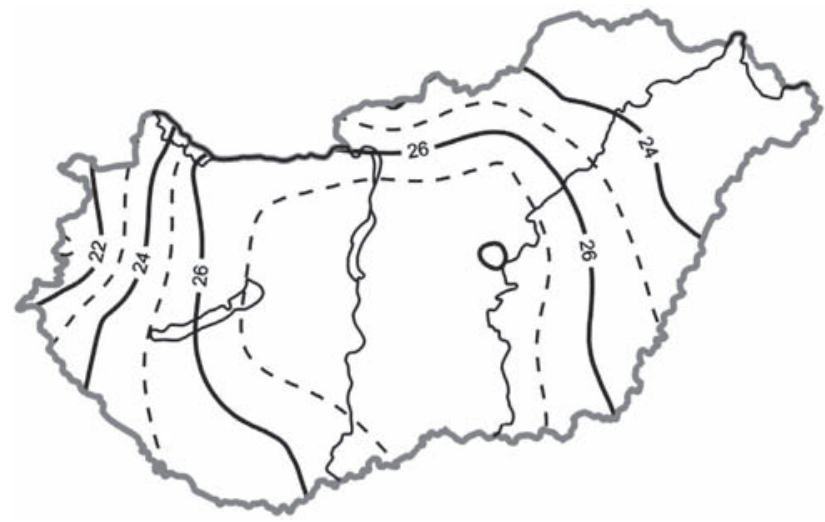

Figure 5 - Mean values of the coefficients of variation of absolute temperature minima in winter measured at 16 stations over a period of 1951-2010

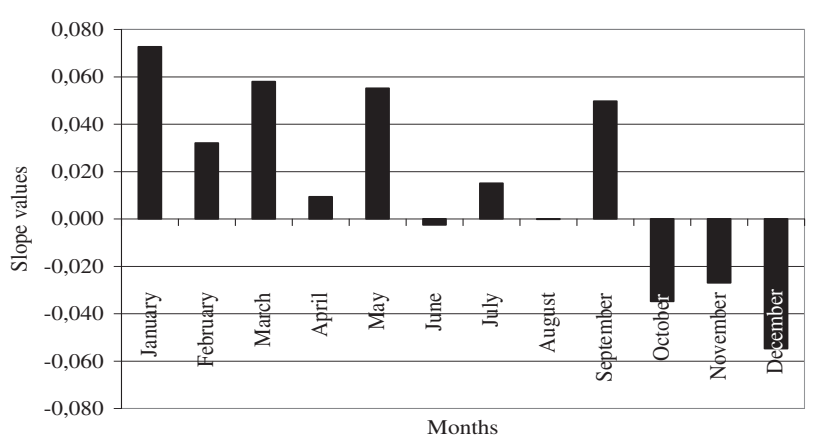

Figure 6 - The mean monthly slopes of the linear trendfunction of absolute temperature minima measured on 16 stations (1951-2010)

no change experienced, whereas in the Subalpine region, the increment of is yearly nearly $0.1^{\circ} \mathrm{C}$. In the following decennia, the absolute minima will rise in the Transdanubian area by $0.6-1.0{ }^{\circ} \mathrm{C}$ provided the other components will not change. In the central Danube-Tisza region the rise of temperature will be $0.2-0.4{ }^{\circ} \mathrm{C} / 10$ years, whereas the SE (south part of the Tisza region) will not change regarding the mean temperatures. In NW, the intense rising tendency of spring temperatures is significant (on $\mathrm{P}=1 \%$ level)

At the overwhelming majority of the stations (94\%) a rising spring temperature has been signalised, however, $40 \%$ of the cases was not significant. The three spring months do not show uniform tendencies of changes. In March, the rise of absolute temperature minima culminated and was followed by May and April. In April, there was a slight reduction of temperatures $\left(0.1^{\circ} \mathrm{C} / 10\right.$ years $)$ at some stations about the northern region in some communities (38\% of the database).

The changes observed in absolute minimum temperatures during winter are paralleled by similar findings on the whole area of the country (Figure 8). All figures of the database indicate the same increasing tendencies. The most intense increment of the absolute minimum temperatures was found on the Northern region of the country. In Transdanubia and the Northern mountains in the middle of the country, the increment attains $1{ }^{\circ} \mathrm{C} / 10$ year. Going from south to north or from east to west, the tendency varies between 0.4 ${ }^{\circ} \mathrm{C} / 10$ years and $0.8{ }^{\circ} \mathrm{C} / 10$ years in the absolute minimum

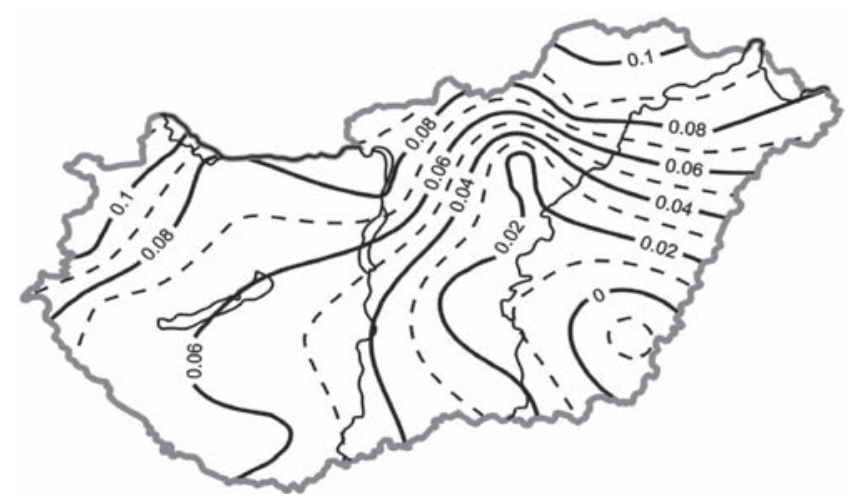

Figure 7 - The spatial distribution of slopes of the trendfunction of absolute temperature minima in spring measured at 16 stations over a period of 1951-2010

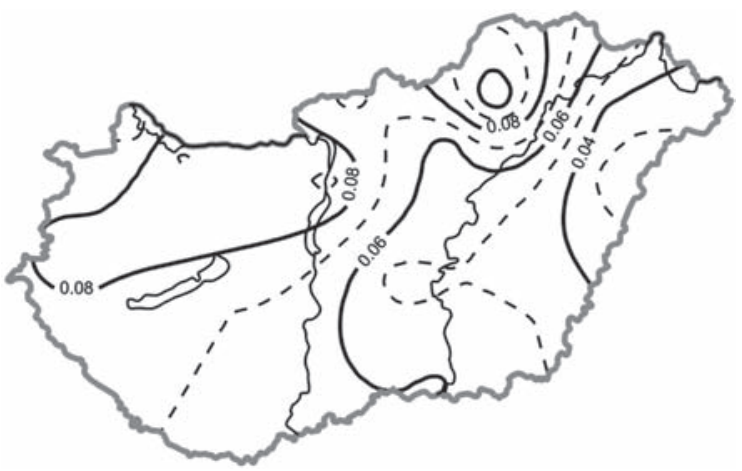

Figure 8 - The spatial distribution of slopes of the trend function of absolute temperature minima in winter measured at 16 stations over a period of 1951-2010

temperatures. The less intense increment was found east to the Tisza river, i.e. around $0.4{ }^{\circ} \mathrm{C} / 10$ years.

The change proved to be significant $(\mathrm{P}=5 \%)$ on the $25 \%$ part of the country.

Regarding all 16 stations, the most change was found on $80 \%$ of the surface in May. The absolute minimum temperatures rose in February and November too, but was less significant (i.e. 95\%) as presented in Figure 9.

The seasonal changes of the absolute minimum temperatures are expressed by the slope of the regression curves of the linear trendfunction as showing the intensity

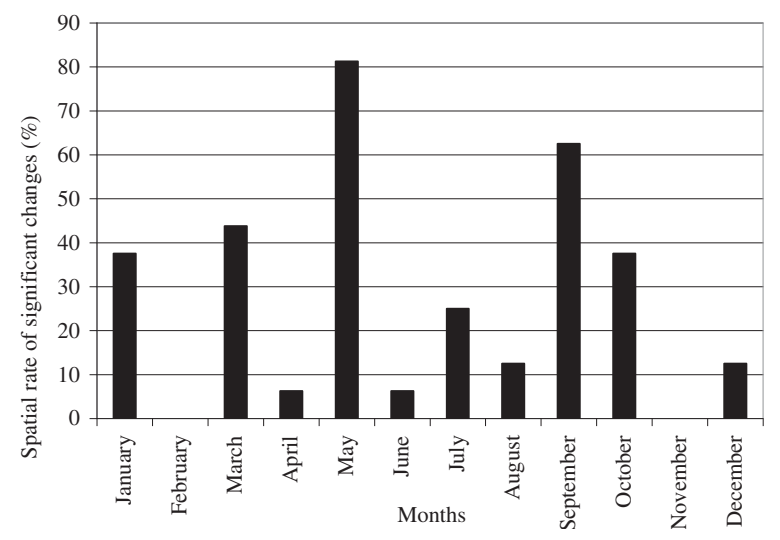

Figure 9 - The temporal distribution of changes of absolute minimum temperatures measured at the 16 stations, where the significance was generally on the $95 \%$ level for the period of 1951-2010 
Table 2 - Values of the slope of the linear trendfunction regarding the absolute minimum temperatures measured at 16 stations in spring and in winter (1951-2010)

\begin{tabular}{|l|c|c|}
\hline \multicolumn{1}{|c|}{ Slope ABS. MIN.TEMP. } & spring & winter \\
\hline Balassagyarmat & 0.0948 & 0.0676 \\
\hline Békéscsaba & -0.0157 & 0.0492 \\
\hline Budapest & 0.0805 & 0.0925 \\
\hline Debrecen & 0.0489 & $\mathbf{0 . 0 2 6 3}$ \\
\hline Győr & 0.0741 & 0.0909 \\
\hline Iregszemcse & 0.0519 & 0.0701 \\
\hline Kecskemet & $\mathbf{0 . 0 1 2 1}$ & 0.0466 \\
\hline Kompolt & 0.0136 & 0.0562 \\
\hline Miskolc & 0.0909 & $\mathbf{0 . 1 0 9 5}$ \\
\hline Mosonmagyaróvár & $\mathbf{0 . 1 0 7 3}$ & 0.0663 \\
\hline Nyíregyháza & 0.0837 & 0.0361 \\
\hline Pécs & 0.0620 & 0.0663 \\
\hline Szeged & 0.0280 & 0.0608 \\
\hline Szolnok & 0.0204 & 0.0528 \\
\hline Szombathely & 0.1039 & 0.0813 \\
\hline Zalaegerszeg & 0.0649 & 0.0803 \\
\hline min & $\mathbf{0 . 0 1 2 1}$ & $\mathbf{0 . 0 2 6 3}$ \\
\hline max & $\mathbf{0 . 1 0 7 3}$ & $\mathbf{0 . 1 0 9 5}$ \\
\hline difference & 0.0952 & 0.0832 \\
\hline mean & $\mathbf{0 . 0 5 7 6}$ & $\mathbf{0 . 0 6 5 8}$ \\
\hline rate of decline (\%) & 0 \\
\hline rate of increment (\%) & 100 \\
\hline
\end{tabular}

of change at the stations. In Table 2, it is clear that at each station, except Békéscsaba, the slope of curves were positive meaning the rise of the absolute minimum temperatures all over the country. In spring, the most intense rise of absolute minima is found at Mosonmagyaróvár (NW) whereas the less intense rise at Kecskemét (centre). During the winter season, Miskolc produced the most intense rise, whereas Debrecen the less intense.

An important question should be answered: which of the stations will produce significant changes regarding the absolute minimum temperatures along the time series of data. The coefficient of correlation will prove the significance on the $\mathrm{P}=5 \%$ level between the fitted trendfunction and the data registered. As a matter of fact, $37.5 \%$ of the stations signalised significant rise in the spring (Table 3). During winter, the rise appeared at $25 \%$ of the stations.

\section{Conclusion}

Results presented show it clearly what kind of changes may occur in the weather during different seasons especially extreme minimum temperatures on the basis of time series over a period of 60 years. The spatial distribution proves significant differences, due to orographical and partially
Table 3 - Coefficients of correlation between the values of the linear trendfunction and the data of absolute minimum temperatures raised on the 16 stations during spring and during winter (1951-2010)

\begin{tabular}{|l|c|c|}
\hline \multicolumn{1}{|c|}{ ABS. MIN. TEMP. COEF. CORR. } & Spring & Winter \\
\hline Balassagyarmat & 0.31 & 0.23 \\
\hline Significasnt rise of Békéscsaba & 0.07 & 0.16 \\
\hline Budapest & 0.32 & 0.33 \\
\hline Debrecen & 0.21 & $\mathbf{0 . 1 0}$ \\
\hline Györ & 0.24 & 0.30 \\
\hline Iregszemcse & 0.17 & 0.22 \\
\hline Kecskemet & $\mathbf{0 . 0 4}$ & 0.15 \\
\hline Kompolt & 0.05 & 0.20 \\
\hline Miskolc & 0.33 & $\mathbf{0 . 3 8}$ \\
\hline Mosonmagyaróvár & $\mathbf{0 . 3 5}$ & 0.26 \\
\hline Nyíregyháza & 0.33 & 0.13 \\
\hline Pécs & 0.25 & 0.26 \\
\hline Szeged & 0.11 & 0.19 \\
\hline Szolnok & 0.08 & 0.16 \\
\hline Szombathely & 0.32 & 0.35 \\
\hline Zalaegerszeg & 0.19 & 0.28 \\
\hline min & 0.04 & 0.10 \\
\hline max & 0.35 & 0.38 \\
\hline difference & 0.2 & 0.28 \\
\hline mean & sign & sign \\
\hline sign (95\%) & 6.2 \\
\hline Number of stations with significant data & 4 \\
\hline Ratio of stations with significant data & 0.5 & 25 \\
\hline
\end{tabular}

rheological factors. Increasing temperatures are not observed in any season nor in any month. In spring, the temperature of extreme minima is increasing significantly on a larger area.

The cases of increasing temperatures were more frequent in winter than in spring at a number of stations. The increment of mean winter temperatures is also attributed to the higher absolute daily maxima.

\section{Acknowledgement}

This study is funded by TECH_08-A3/2-2008-0373 and TECH_08-A4/2-2008-0138 projects.

\section{References}

Bartholy J., Pongrácz R., Matyasovszky I., Schlanger V. (2003): A globális klímaváltozás várható tendenciái a Kárpát medence területére. In IV: Erdő és Klíma Konferencia, Bakonybél

Csapó P. (1984): Szőlőültetvények téli fagykérénak becslése. Légkör, (1): 19-21.

Cselőtei L. 1998: Az időjárás hatása a növények vízellátottságára és termésére. Meteorológiai tudományos napok '98, OMSz, Budapest $7-14$. 
Domonkos P. (2001): A napi léghőmérséklet extrém anomáliáinak időbeli struktúrái. Éghajlati és Agrometeorológia Tanulmányok 8: 104.

Dunkel Z., Füri J., Justyák J., Kozma F. (1984): A fagykárok meteorológiai háttere szőlő̈ultetvényekben. Beszámolók az 1981-ben végzett tudományos kutatásokról. Országos Metetorológiai Szolgálat, Budapest 365-366.

Fekete L. (1980): A késő tavaszi és kora őszi fagyok fellépésének makroszinoptikus körülményei. OMSZ Beszá,olók az 1980-ban végzett tudományos kutatásokról. 249-255.

Harnos N. (2003): Klimaváltozás hatásának szimulációs vizsgálata az őszi búza produkciójára. ,AGRO-21” Füzetek, 31: 56-73.

Mika J. (1988): A globális felmelegedés regionális sajátosságai a Kárpát-medencében. Időjárás (92): 178-189.

Mika J. (1991): Nagyobb globális fölmelegedés várható magyarországi sajátosságai. Időjárás (96): 265-278.
Mika J., Bartholy J., Szeidl L., Szentimrei T. (2001). Éghajlati idősorok szélsőségeinek alakulása Magyarországon. Légkör XLV. 4: 9-13.

Szilágyi T. (1982): A későtavaszi fagyok és védekezési lehetőségei. Légkör, (1): 2-8.

Varga Z., Varga-Haszonits Z., Lantos Zs. (2001)A kukorica hőmérsékleti és nedvességi igényének meghatározása a terméshozamokra gyakorolt hatás alapján. Növénytermelés. 50 (2-3): 345-358.

Varga Z. (2003): Fagyok előfordulásának bioklimatológiai jellemzői az 1951-1990 közötti időszakban. Acta Agronomica Óváriensis. 45 (2): 167-177.

Varga-Haszonits Z., Varga Z., Lantos Zs. (2002): Az agroökoszisztémák és a meteorológiai küszöbértékek által meghatározott időszakok. Acta Agronomica Óváriensis. 44 (2): 103-119.

Varga-Haszonits Z. (2003): Az éghajlat változás mezőgazdasági hatásának elemzése, éghajlati szcenáriók. „AGRO-21” füzetek. Az Agrárgazdaság jövőképe. 31: 9-28. 